\title{
Mineral bio-accessibility and intrinsic saccharides in breakfast flakes manufactured from sprouted wheat
}

\author{
Elien Lemmens $^{\mathrm{a}, *}$, Lomme J. Deleu ${ }^{\mathrm{a}}$, Niels DE. brier ${ }^{\mathrm{a}, 1}$, ErikSmolders ${ }^{\mathrm{b}}$, Jan A. Delcour ${ }^{\mathrm{a}}$ \\ ${ }^{a}$ Laboratory of Food Chemistry and Biochemistry, And Leuven Food Science and Nutrition Research Centre (LFoRCe), KU Leuven, Kasteelpark Arenberg 20, B-3001 Leuven, Belgium \\ ${ }^{\mathrm{b}}$ Division of Soil and Water Management, KU Leuven, Leuven, Belgium
}

\section{A R T I C L E I N F O}

\section{Keywords}

Phytate

Sugars

Germination

Hardness

Cereal flakes

\begin{abstract}
A B S T R A C T
The objective was to produce breakfast flakes by extrusion using whole meal from sprouted wheat to increase mineral bio-accessibility and provide intrinsic sweetness without compromising their textural properties. Resting the ingredient mixture containing whole meal from (sprouted) wheat at $50{ }^{\circ} \mathrm{C}$ and $\mathrm{pH} 3.8$ for $1 \mathrm{~h}$ prior to flake production allowed in situ endogenous phytase action. This resulted in end-products that had higher bio-accessibilities of $\mathrm{Fe}(29-38 \%)$ and of $\mathrm{Zn}(17-32 \%)$ than corresponding values for control flakes (8\% and $8 \%$, respectively). Further, the sweetness of breakfast flakes can be enhanced as sprouted grains are a source of intrinsic saccharides released by starch degrading enzymes. Substituting control wheat by sprouted wheat in the breakfast flake recipe led to darker flakes with increased density corrected hardness. The latter was due to lower bulk densities and higher starch crystallinity than observed for control flakes. Nevertheless, the flakes still had 70-80\% of their initial hardness after soaking for $30 \mathrm{~s}$ in semi-skimmed milk. The here developed wheat flakes meet the growing consumer interest in healthy and tasty foods. Further, the presented technology lowers the need for extrinsic micronutrient fortification by making full use of the nutritional potential of wheat grains.
\end{abstract}

\begin{tabular}{l} 
Abbreviations used \\
$\mathrm{F}_{\max }$ \\
maximum force \\
ICP-MS \\
inductively coupled plasma mass spectrometry \\
$\mathrm{N}_{\mathrm{sr}}$ \\
spatial frequency of ruptures \\
rpm \\
rotations per minute \\
\hline
\end{tabular}

\section{Introduction}

Extrusion cooked breakfast flakes are popular with the consumer because of their texture and taste, shelf life and ease of in home preparation (Brennan, Derbyshire, Tiwari, \& Brennan, 2013).

Extruders generally consist of a pre-conditioning system, a feeding system, a screw, a barrel and a die with a cutter (Navale, Swami, \& Thakor, 2015). The product shape and quality depend on the ingredi- ents, their moisture content, the barrel temperature, the speed and configuration of the screw(s) and the type of extruder (i.e. single-screw versus twin-screw) (Brennan et al., 2013). During extrusion, the rotating screw(s) propel(s) the cereal material forward at elevated pressure, shear and temperature. At the end of the screw the material is forced through the die. The sudden pressure drop at the interface between die and atmosphere results in evaporation of water and product expansion to a degree which depends on the rheological properties of the material, its composition and moisture content, its temperature and the geometry of the die. The extrudate is usually cut by a rotating knife on the outer side of the die (Brennan et al., 2013; Brennan, Merts, Monro, Woolnough, \& Brennan, 2008; Le Corre, 2006; Sacchetti, Pittia, \& Pinnavaia, 2005). For breakfast flake production, the extruded pellets are then flaked between two steel rollers and the resulting flakes are toasted at typically $274-329^{\circ} \mathrm{C}$ for a short time (e.g. $90 \mathrm{~s}$ ) to reduce their moisture content (Ding, Ainsworth, Plunkett, Tucker, \& Marson, 2006). This heat treatment leads to their specific crisp texture, flavour and colour attributes (Le Corre, 2006).

Wheat (Triticum aestivum L.) white flour is a common raw material for breakfast flakes. As it contains less dietary fibre and important nutrients such as minerals and vitamins than wheat whole meal, breakfast

\footnotetext{
* Corresponding author.

E-mail addresses: elien.lemmens1@kuleuven.be (E. Lemmens); lomme.deleu@kuleuven.be (L.J. Deleu); niels.debrier@rodekruis.be (N.DE. brier); erik.smolders@kuleuven.be (E. Smolders); jan.delcour@kuleuven.be (J.A. Delcour)

1 Current address: Rode Kruis-Vlaanderen, Motstraat 42, 2800 Mechelen, Belgium
} 
flakes are often fortified with vitamins and minerals (Woods \& Walker, 2007).

Using whole meal rather than refined white flour in the extrusion process would lead to breakfast flakes with better nutritional profiles on account of their higher dietary fibre, mineral and vitamin contents. Regretfully, the bio-accessibility of iron (Fe) and zinc ( $\mathrm{Zn}$ ), i.e. the amount of these minerals released from the food matrix upon digestion, is only $3-5 \%$ as phytic acid, the main storage form of phosphorus, chelates them (De Brier et al., 2016; Lemmens et al., 2018). A further concern is that commercial breakfast flakes often contain high contents of added sugar (Woods \& Walker, 2007) and as a result, on a serving portion weight basis, even contain less minerals and vitamins than if less or no sugar is added.

To overcome the above hurdles, it is useful to sprout cereal grains. Indeed, during sprouting, hydrolytic enzymes are activated or de novo synthesised to fuel seedling growth (Bewley, Bradford, Hilhorst, \& Nonogaki, 2013). Amylase action leads to (partial) hydrolysis of starch for the mobilisation of sugars to the growing embryo and therefore increases the intrinsic saccharide content in cereal grains (Duke, 2009). Further, the increase in endogenous phytase activity as a result of sprouting directly leads to phytate hydrolysis and thus to release of bound minerals and improved mineral bio-accessibility (Greiner, Jany, \& Alminger, 2000; Lemmens, De Brier, Goos, Smolders, \& Delcour, 2019).

Extruded products have been produced from recipes containing whole meal (30-100\%) from sprouted oats (Kince et al., 2017; Kruma et al., 2018), triticale (Kince et al., 2017; Kruma et al., 2018), rye (Heiniö et al., 2003; Kince et al., 2017; Kruma et al., 2018), wheat (Kince et al., 2017; Kruma et al., 2018; Singkhornart, Gu, \& Ryu, 2013) and barley (Kince et al., 2017; Kruma et al., 2018; Singkhornart et al., 2013). In the study by Heiniö et al. (2003, pp. 533-545), a trained panel judged sprouted and extruded rye to have a grainy and fresh flavour but hard texture. Singkhornart et al. (2013) found that extruding sprouted wheat decreases its phytic acid content.

To the best of our knowledge, studies on the impact of using whole meal from sprouted wheat in a breakfast flake making process on intrinsic saccharide formation, on mineral bio-accessibility and on texture properties of flakes have not been performed. Against this background, the aim of this study was to manufacture breakfast flakes with high levels of bio-accessible minerals and sweet intrinsic saccharides by using sprouted whole wheat grains as ingredients and allowing in situ enzyme action during the production process. We hypothesised that rationally modifying the breakfast flake making process would allow optimal in situ endogenous phytase and amylase action and, hence, the release of minerals from its chelates and saccharides from starch, respectively. This can then lead to breakfast flakes with an improved nutritive value, a unique flavour profile and a cleaner label, since less or no mineral fortification and sugar addition is needed.

\section{Materials and methods}

\subsection{Materials}

All chemicals and reagents were of at least analytical grade and purchased from Sigma-Aldrich (Bornem, Belgium) unless otherwise specified. Winter wheat [Cellule, moisture and protein ( $\mathrm{N} \times 5.7)$ content $12.6 \mathrm{~g} / 100 \mathrm{~g}$, and $9.7 \mathrm{~g} / 100 \mathrm{~g}$ of dry matter $(\mathrm{dm})$, respectively] was supplied by Limagrain (Avelgem, Belgium). A reference wheat (NIST1567) flour sample with certified element composition was obtained from the National Institute of Standards and Technology (Gaithersburg, MD, USA). Salt, sucrose and glucose were food grade.
Kellogg's All-Bran flakes (made from $66 \mathrm{~g} / 100 \mathrm{~g}$ whole wheat meal, $21 \mathrm{~g} / 100 \mathrm{~g}$ wheat bran and $6 \mathrm{~g} / 100 \mathrm{~g}$ oat meal and fortified with vitamins and $\mathrm{Fe}$ ) were purchased from a local supermarket and used for comparative reasons. Ultra-high temperature treated semi-skimmed milk was also purchased from a local supermarket and stored and used at $23 \pm 1{ }^{\circ} \mathrm{C}$.

\subsection{Steeping and sprouting of wheat grains}

To study their functionality in breakfast flake making, control wheat grains were steeped and sprouted at least in triplicate in a pilot-scale micro malting system (Joe White Malting Systems, Perth, Australia) at $15{ }^{\circ} \mathrm{C}$. The steeping in excess water consisted of three successive wet stages $\left(7,7\right.$ and $3 \mathrm{~h}$ at $\left.15^{\circ} \mathrm{C}\right)$ alternated by two intermediate $6 \mathrm{~h}$ air rest stages at $15{ }^{\circ} \mathrm{C}$. The imbibed grains were then sprouted for $48 \mathrm{~h}$ at $15^{\circ} \mathrm{C}$. The processed wheat grains were flash-frozen using liquid $\mathrm{N}_{2}$ and freeze-dried (to a moisture content of $5.0 \mathrm{~g} / 100 \mathrm{~g}$ ). These sprouted wheat grains and control (i.e. unsprouted) wheat grains were then milled with a FOSS Tecator (HillerØd, Denmark) cyclotec 1093 sample mill into whole meal $(<500 \mu \mathrm{m})$ prior to breakfast flake production. In a next step, control flakes and breakfast flakes derived from sprouted wheat were produced in triplicate, both for the standard and modified process ( $c f r$. 2.3). In addition, whole meal blends containing $75 \mathrm{~g} / 100 \mathrm{~g} \mathrm{dm}$ control wheat and $25 \mathrm{~g} / 100 \mathrm{~g} \mathrm{dm}$ sprouted wheat were used for breakfast flake making in duplicate with both the standard and the modified process (cfr. 2.3).

\subsection{Production of breakfast flakes}

Standard breakfast flakes were made on pilot scale at the Institut für Getreideverarbeitung (IGV, Potsdam, Germany) essentially as in Joye, Lamberts, Brijs, and Delcour (2011) and De Brier et al. (2015) from a recipe consisting of $358 \mathrm{~g} \mathrm{dm}$ wheat whole meal, $30.0 \mathrm{~g}$ sucrose, $10.0 \mathrm{~g}$ glucose and $2.0 \mathrm{~g}$ salt. The sucrose, glucose and salt were dissolved in the amount of water $(160 \mathrm{ml})$ needed to obtain $30 \mathrm{~g} / 100 \mathrm{~g}$ moisture in the ingredient bill. Next, all ingredients were blended for $120 \mathrm{~s}$ in a Stephan UMS 5 electronic mixer (Hameln, Germany), mixed by hand and then mixed again for $30 \mathrm{~s}$ to ensure proper homogenisation. After a $30 \mathrm{~min}$ rest at room temperature, the mixture was extruded with a Brabender (Duisburg, Germany) single screw extruder [65-100 ${ }^{\circ} \mathrm{C}, 1-4$ bar, screw speed 100 rotations per min (rpm), nozzle diameter $6 \mathrm{~mm}$ ] to form pellets with a moisture level of 25.0-28.0 g/ $100 \mathrm{~g}$ (Sartorius Moisture Analyser MA30, Göttingen, Germany). These were then flaked at room temperature with a roller mill (Shule, Hamburg, Germany) at a gap setting of $0.25 \mathrm{~mm}$ and air-dried overnight. When needed, the resultant flakes were conditioned in a climate chamber (HC0057, Heraeus Vötsch, Hanau, Germany) at $30{ }^{\circ} \mathrm{C}$ and $80 \%$ relative humidity for $4 \mathrm{~h}$ to a moisture content of $12.0-15.0 \mathrm{~g} / 100 \mathrm{~g}$. Finally, they were toasted in a drum roaster (Probat-Werke von Gimborn Maschinenfabrik, Emmerich am Rhein, Germany) for $3 \mathrm{~min}$ at $248{ }^{\circ} \mathrm{C}$ resulting in a moisture level of 3.0-5.0 g/100 g.

Samples were withdrawn immediately after mixing, resting, extrusion, flaking and roasting. All samples but the roasted flakes were stored at $-20{ }^{\circ} \mathrm{C}$ and freeze-dried. After freeze-drying, these samples and part of the roasted flakes were ground with an IKA-mill (Staufen, Germany).

For the modified production of breakfast flakes, acid incubation was executed by adding $160 \mathrm{ml} 100 \mathrm{mmol} / \mathrm{l}$ sodium acetate buffer ( $\mathrm{pH} 3.8$ ) to the ingredients instead of water $(160 \mathrm{ml})$ and resting the ingredient mixture prior to extrusion at $50{ }^{\circ} \mathrm{C}$ for $60 \mathrm{~min}$ instead of at room temperature for $30 \mathrm{~min}$. Samples were withdrawn, stored, freeze-dried and ground as described above. 


\subsection{Analysis of breakfast flakes}

Moisture contents of ground flakes were determined according the AACC method 44-15.02, in which samples $(2.0 \mathrm{~g})$ are dried for $3 \mathrm{~h}$ at $130{ }^{\circ} \mathrm{C}$.

The CIELAB colour space of ground flakes was determined in fivefold with a colorimeter (ColorFlex EZ Spectrophotometer, Hunterlab, Murnau, Germany). This model expresses colour as three values: $L *$ for the lightness from black (0) to white (100), a* from green ( - ) to red $(+)$ and $\mathrm{b}$ * from blue (-) to yellow (+) (Ibraheem, Hasan, Khan, \& Mishra, 2012).

The bulk density $(\mathrm{g} / \mathrm{l})$ of breakfast flakes relates to their degree of expansion, their stacking and thus to their sizes and shapes (De Brier et al., 2015). It was calculated from the average volume of three samples of $100 \mathrm{~g}$ of flakes each brought in a 1.01 graduated cylinder $(7.0 \mathrm{~cm}$ diameter). Flakes of intermediate bulk density values are desired by the consumer (Oliveira, Schmiele, \& Steel, 2017; Wojtowicz et al., 2015).

The length and thickness of flakes was measured with a digital calliper. We here report the averages obtained for 20 flakes.

The texture of flakes was analysed using an Instron 5943 (Norwood, MA, USA) testing machine equipped with a $1 \mathrm{kN}$ load cell as in De Brier et al. (2015). Tests were performed in sixfold in bulk (15.0 g) with a five-blade Kramer shear cell. The blades of the cell forced the breakfast flakes through the open spaces at the bottom of the cell. Samples were compressed at $120 \mathrm{~mm} / \mathrm{min}$ at room temperature. The maximum force $\left(\mathrm{F}_{\max },[\mathrm{N}]\right)$ was taken as a measure for the hardness of the sample. The spatial frequency of ruptures $\left(\mathrm{N}_{\mathrm{sr}},\left[\mathrm{mm}^{-1}\right]\right.$ ) was calculated from the force-displacement curves using the following equation (Agbisit, Alavi, Cheng, Herald, \& Trater, 2007):

$N s r=\frac{n}{d}$

with $\mathrm{n}$ the number of peaks and $\mathrm{d}$ the travel distance of the probe.

A most important quality parameter of breakfast flakes is how well their texture withstands soaking in milk (De Brier et al., 2015). Here, $15.0 \mathrm{~g}$ of breakfast flakes were soaked in triplicate during $30 \mathrm{~s}$ in $300 \mathrm{ml}$ semi-skimmed milk in a tea sieve at $23 \pm 1{ }^{\circ} \mathrm{C}$ under continuous stirring (200 rpm) basically as in Sacchetti, Pittia, Biserni, Pinnavaia, and Rosa (2003) and De Brier et al. (2015). The soaked flakes were drained for $30 \mathrm{~s}$ to remove excess milk from the surface and texture analysis was performed as described above.

High Performance Anion Exchange Chromatography (HPAEC) with Pulsed Amperometric Detection (PAD) was performed in triplicate with a Dionex ICS5000 system (Dionex, Sunnyvale, CA, USA) to quantify the soluble saccharides formed during (modified) breakfast flake production. Extracts were obtained by adding $10.0 \mathrm{ml}$ deionised water containing $2.0 \mathrm{mg}$ rhamnose (internal standard) to $80-100 \mathrm{mg}$ accurately weighed sample, extracting ( $30 \mathrm{~min}, 150 \mathrm{rpm}, 7^{\circ} \mathrm{C}$ ) and centrifuging (10 min, $1500 \mathrm{~g}, 7^{\circ} \mathrm{C}$ ). An aliquot $(50 \mu \mathrm{l})$ of supernatant was then added to $950 \mu \mathrm{l}$ deionised water and after filtration $(0.22 \mu \mathrm{m})$, a subsample $(12.5 \mu \mathrm{L})$ was injected on Carbopac PA-100 guard and PA-100 anion exchange $(250 \times 4 \mathrm{~mm})$ columns. The mobile phase $(1.0 \mathrm{ml} / \mathrm{min})$ during equilibration and the first $5 \mathrm{~min}$ of the run was $100 \mathrm{mmol} / \mathrm{l} \mathrm{NaOH}$. The sodium acetate concentration in $100 \mathrm{mmol} / \mathrm{l} \mathrm{NaOH}$ was then increased by $3.6 \mathrm{mmol} / 1 / \mathrm{min}$ over $25 \mathrm{~min}$. Glucose, fructose, sucrose, maltose and maltotriose standards were used to identify and quantify the saccharides $(\mathrm{g} / 100 \mathrm{~g}$ of $\mathrm{dm})$. The total soluble saccharide contents $(\mathrm{g} / 100 \mathrm{~g}$ of $\mathrm{dm})$ in the different samples were here calculated as the sum of the measured glucose, fructose, sucrose, maltose and maltotriose contents. Based on the obtained soluble saccharide contents of the samples, their relative sweetness values were calculated using the following equation (Lavic, 2011):

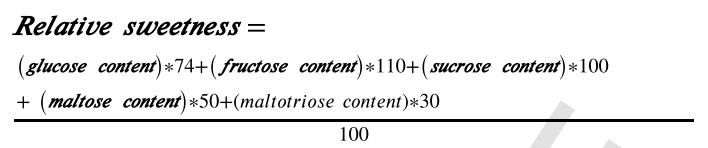

with 74, 110, 50 and 30 the relative sweetness factors of glucose, fructose, maltose and maltotriose, respectively, compared to that of sucrose which has a relative sweetness value of 100 .

Phytate contents in wheat flakes were determined at least in triplicate after acid extraction of myo-inositol phosphates (K-Phyt assay kit, Megazyme, Bray, Ireland) as described in Lemmens et al. (2018). The concentration of free phosphates in the extracts was subtracted from the phosphate concentration after subsequent breakdown of myo-inositol phosphates by phytase and alkaline phosphatase. Phytate contents were obtained by dividing bound phosphorus contents by 0.282 .

\subsection{Iron and zinc bio-accessibility}

An in vitro digestion procedure was carried out essentially as in Minekus et al. (2014) with slight modifications to make it suited for evaluating mineral bio-accessibility (Lemmens, De Brier et al., 2019; Lemmens et al., 2018). This procedure simulates the digestion process in mouth, stomach and small intestine. An aliquot $(3.0 \mathrm{~g} \mathrm{dm})$ of ground breakfast flakes suspended in triplicate in $50.0 \mathrm{ml}$ deionised water ( $\mathrm{pH}$ 7.2) was incubated for $5 \mathrm{~min}$ at $37^{\circ} \mathrm{C}$ under magnetic stirring (250 rpm). After adjusting the $\mathrm{pH}$ to 2.0 with $150 \mathrm{mmol} / \mathrm{l} \mathrm{HCl}$ and adding $2.0 \mathrm{ml}$ pepsin solution (Sigma P-7012, $2.0 \mathrm{mg} / \mathrm{ml}$ ), samples were incubated for $120 \mathrm{~min}$ at $37{ }^{\circ} \mathrm{C}$ under magnetic stirring (250 rpm). Next, $13.4 \mathrm{ml}$ pancreatin (Sigma P-3292) solution $(5.0 \mathrm{mg} / \mathrm{ml}$ in $150 \mathrm{mmol} /$ 1 sodium bicarbonate) was added and the $\mathrm{pH}$ was adjusted to 6.8 with $1.0 \mathrm{~mol} / 1 \mathrm{NaOH}$. The mixture was then incubated for $3 \mathrm{~h}$ at $37{ }^{\circ} \mathrm{C}$ under magnetic stirring $(250 \mathrm{rpm})$. Finally, the suspensions were centrifuged (15 min, $9800 \mathrm{~g}$, room temperature) and the obtained supernatants (digested fractions) and residues (undigested fractions) were flash-frozen with liquid $\mathrm{N}_{2}$ and freeze-dried.

The elemental contents of the (processed) wheat samples and the freeze-dried digested fractions thereof were determined at least in triplicate using inductively coupled plasma mass spectrometry (ICP-MS). Samples $(50 \mathrm{mg},<200 \mu \mathrm{m}$ ) were weighed into glass tubes and digested with $1.0 \mathrm{ml}$ ultrapure $250 \mathrm{ml} / 1 \mathrm{HNO}_{3}$ and subsequently with $2.0 \mathrm{ml}$ aqua regia $\left(750 \mathrm{ml} / 1\right.$ ultrapure $\mathrm{HCl}$ and $250 \mathrm{ml} / 1$ ultrapure $\left.\mathrm{HNO}_{3}\right)$ at $150{ }^{\circ} \mathrm{C}$, followed by dilution with Milli-Q water $\left(18.2 \mathrm{M} \Omega \mathrm{cm}\right.$ at $25{ }^{\circ} \mathrm{C}$; Milli-Q Plus, Merck Millipore, Darmstadt, Germany) to $10.0 \mathrm{ml}$. The elements in the different samples and the NIST1567 wheat reference were analysed by ICP-MS with an Agilent 7700x (Santa Clara, CA, USA). The reported elements were recovered within $10 \%$ of the certified values.

The elemental bio-accessibility was then calculated as follows:

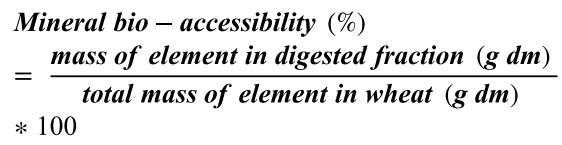

For each element, the difference between the concentration in breakfast flakes and in the weighted average concentration of all corresponding fractions obtained after the in vitro digestion assay varied between 7 and $15 \%$.

The molar ratios of phytate to Fe or $\mathrm{Zn}$ were calculated as the millimoles of phytate per $\mathrm{kg}$ breakfast flakes divided by the millimoles of Fe or $\mathrm{Zn}$ per kg breakfast flakes, respectively. This molar ratio is a useful index for predicting the in vivo mineral bio-availability (i.e. absorption by the human body) (Morris \& Ellis, 1989). 


\subsection{Statistical analyses}

Statistical analyses were conducted using the Statistical Analysis System software 14.0 (SAS Institute, Cary, NC, USA). Given the small amount of samples ( $n=2$ or $n=3$ ), we first performed two non-parametric tests: the Van der Waerden test and the Kruskal Wallis test. Both tests confirmed that there were significant differences $(P<0.05)$ between responses for all parameters under study (colour, bulk density, phytate contents, etc.). Given that the residuals of ANOVA seemed to be normally distributed (data not shown), we here reported the results of one-way ANOVA with post hoc Tukey multiple comparison testing to verify whether mean values of responses under study were significantly $(\mathrm{P}<0.05)$ different.

The treatment was the breakfast flake making process using either control wheat, sprouted wheat or a blend of the former. Several chemical and physical parameters were relevant with several technical replicates of the same material. Data of the technical replicates were averages and only the mean values were used for each of the true independent treatment replicates, i.e. $\mathrm{n}=2$ for the blend and $\mathrm{n}=3$ for control and sprouted wheat.

\section{Results and discussion}

The starting point for modifying the production process was that although there was a substantial increase in phytase activity during sprouting, phytate breakdown was limited to only $15 \%$ (Lemmens, De Brier et al., 2019). Lemmens et al. (2018) showed that hydrothermal processing of sprouted $\left(15{ }^{\circ} \mathrm{C}, 120 \mathrm{~h}\right)$ wheat at $50{ }^{\circ} \mathrm{C}$ and $\mathrm{pH} 3.8$ for $24 \mathrm{~h}$ reduced phytate content by $95 \%$. We here simulated these optimal conditions for phytase action in the modified process by replacing the water in the ingredient bill by $100 \mathrm{mmol} / \mathrm{l}$ sodium acetate buffer (pH 3.8) and implementing a resting period of $1 \mathrm{~h}$ at $50^{\circ} \mathrm{C}$ prior to extrusion. In addition, such treatment may favour saccharide release from starch as a result of $\alpha$-amylase action under conditions more close to its optimum (pH 5.0, $68{ }^{\circ} \mathrm{C}$ ) (K. Singh \& Kayastha, 2014). Finally, whole meal blends containing $25 \mathrm{~g} / 100 \mathrm{~g}$ sprouted wheat and $75 \mathrm{~g} / 100 \mathrm{~g}$ control wheat were made to check whether there were synergistic effects. For example, one of the questions was whether endogenous enzymes present in sprouted wheat act on control wheat in the ingredient mixture.

\subsection{Colour characteristics of the breakfast flakes}

Kellogg's All-Bran flakes had L*, a* and b* values of 70, 6 and 23, respectively which were comparable to the values obtained for our flakes (Table 1). Indeed, the $L^{*}$ values of the flakes varied from 70 to 82 . Such high values indicate lightness. The $\mathrm{a}^{*}$ values amounted to 3 to 8 , indicating redness and the $b^{*}$ values ranged from 15 to 23 pointing to a more yellowish colour.

Flakes from control wheat had $\mathrm{L}^{*}, \mathrm{a}^{*}$ and $\mathrm{b}^{*}$ values of 82,3 and 15 respectively. The $L^{*}$ values of flakes derived from sprouted wheat and the blend produced using the standard process were lower (70-74) than those of the flakes from control wheat, clearly indicating higher darkness. Further, both $a^{*}(6-8)$ and $b *(21-23)$ values of these flakes were higher than those of flakes made with control wheat.

Wheat sprouting increases the levels of reducing sugars and amino groups both of which partake in Maillard reactions (Lasekan \& Lasekan, 1997; Tian et al., 2010; van Boekel, 2006). The darker colour and the higher redness and yellowness of flakes derived from sprouted wheat and the blend resulted from more intense Maillard reactions during extrusion (S. Singh, Gamlath, \& Wakeling, 2007) and roasting (Coghe, Gheeraert, Michiels, \& Delvaux, 2006).
Table 1

CIELAB colour space ( $\mathrm{L}^{*}, \mathrm{a}^{*}$ and $\mathrm{b}^{*}$ ) of the different breakfast flakes produced using the standard or modified (acid incubation) process. Means and standard deviations of two (blend) or three (control or sprouted wheat) independent treatment replicates are given each measured with five technical repeats. Mean values within one colour component differ significantly $(P<0.05)$ when not sharing the same letter.

\begin{tabular}{|c|c|c|c|}
\hline Breakfast flake type & $\mathrm{L}^{*}$ & $a^{*}$ & $b^{*}$ \\
\hline Kellogg's All-Bran & $70.3 \pm 0.1^{\mathrm{a}}$ & $6.2 \pm 0.1 \mathrm{ab}$ & $23.0 \pm 0.1^{\mathrm{a}}$ \\
\hline $\begin{array}{l}\text { Control wheat, standard } \\
\text { process }\end{array}$ & $81.5 \pm 0.3^{b}$ & $3.3 \pm 0.1^{c}$ & $14.6 \pm 0.4^{b}$ \\
\hline $\begin{array}{l}\text { Control wheat, modified } \\
\text { process }\end{array}$ & $\begin{array}{l}80.0 \pm 0.3 \\
\text { bc }\end{array}$ & $4.4 \pm 0.1 \mathrm{~cd}$ & $17.3 \pm 0.3^{b}$ \\
\hline $\begin{array}{l}\text { Sprouted wheat, standard } \\
\text { process }\end{array}$ & $70.2 \pm 2.4^{\mathrm{a}}$ & $7.6 \pm 0.9^{a}$ & $22.9 \pm 1.3^{\mathrm{a}}$ \\
\hline $\begin{array}{l}\text { Sprouted wheat, modified } \\
\text { process }\end{array}$ & $78.4 \pm 1.7^{c}$ & $\begin{array}{l}4.5 \\
\text { bcd }\end{array}$ & $19.0 \pm 1.1^{\mathrm{a}}$ \\
\hline Blend, standard process & $\begin{array}{l}74.4 \pm 1.1 \\
\text { ac }\end{array}$ & $6.4 \pm 0.5^{a b}$ & $20.5 \pm 0.7^{a}$ \\
\hline Blend, modified process & $\underset{b c}{77.4} \pm 0.4$ & $5.7 \pm 0.2$ bd & $20.3 \pm 0.4^{a}$ \\
\hline
\end{tabular}

Using the modified process for flake production did not have a major impact on the colour characteristics of the resulting flakes (Table 1). Breakfast flakes derived from sprouted wheat using the modified process had significantly higher L* (78) and lower a* (5) values than flakes derived from sprouted wheat using the standard process, probably because of a decreased extent to which Maillard reactions had occurred. We believe that the acidic $\mathrm{pH}$ of 3.8 is at the basis of our observations. Indeed, at low $\mathrm{pH}$ amino groups are less available for Maillard reactions (Ajandouz, Tchiakpe, Dalle Ore, Benajiba, \& Puigserver, 2001; Cerny \& Brifford, 2007; Karseno, Yanto, Setyowati, \& Haryanti, 2017).

\subsection{Bulk density and thickness of the breakfast flakes}

Kellogg's All-Bran flakes had a bulk density of $171 \mathrm{~g} / \mathrm{l}$, compared to $399 \mathrm{~g} / \mathrm{l}$ for flakes derived from control wheat (Table 2). Oliveira et al. (2017) found a bulk density of $178 \mathrm{~g} / \mathrm{l}$ for spherical air oven-dried extrudates with a diameter of $9 \mathrm{~mm}$ derived from $100 \%$ wheat whole meal, while De Brier et al. (2015) found values of 240-330 g/1 for their wheat bran-rich breakfast flakes. Further, Wojtowicz et al. (2015) obtained values in a 200-250 g/l range for extruded breakfast cereals made from $70 \mathrm{~g} / 100 \mathrm{~g}$ wheat whole meal, $10 \mathrm{~g} / 100 \mathrm{~g}$ corn grits, $10 \mathrm{~g} / 100 \mathrm{~g}$ rice flour, $5 \mathrm{~g} / 100 \mathrm{~g}$ sugar and $5 \mathrm{~g} / 100 \mathrm{~g}$ cocoa. The bulk density of flakes produced from sprouted wheat was much lower (198 g/ 1) than that of flakes made from control wheat using the standard production process $(399 \mathrm{~g} / 1)$. This was related to the much higher level of hydrolytic enzymes when sprouted wheat was used (data not shown). Partial hydrolysis of starch and gluten allowed for more product expansion. Substitution of control by sprouted wheat can indeed lower product bulk density readings to values desired by the consumer (Oliveira et al., 2017; Wojtowicz et al., 2015). In addition, flakes from sprouted wheat were thinner $(0.6 \mathrm{~mm})$ than those from control wheat $(0.9 \mathrm{~mm})$. This is explained by the lower resistance of these pellets to the forces imposed by flaking as a result of starch and gluten hydrolysis and thus, a less strong starch/gluten network in the extrudate.

Surprisingly, the bulk density of flakes from sprouted wheat (335 g/ 1) made using the modified production process was significantly higher than that of flakes from sprouted wheat using the standard process (198 g/l). Conditions in the former process $\left(50^{\circ} \mathrm{C}, \mathrm{pH} 3.8\right)$ may have negatively impacted amylase and/or peptidase action. 
Table 2

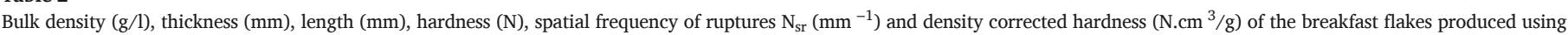

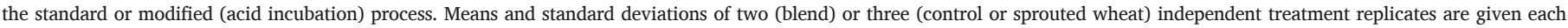

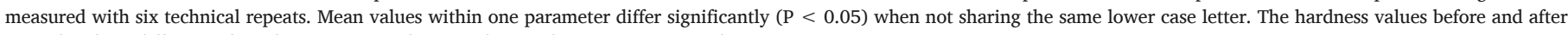
$30 \mathrm{~s}$ of soaking differ significantly $(\mathrm{P}<0.05)$ when not sharing the same upper case letter.

\begin{tabular}{|c|c|c|c|c|c|c|c|}
\hline Breakfast flake type & $\begin{array}{l}\text { Bulk density } \\
(\mathrm{g} / \mathrm{l})\end{array}$ & $\begin{array}{l}\text { Thickness } \\
(\mathrm{mm})\end{array}$ & $\begin{array}{l}\text { Length } \\
(\mathrm{mm})\end{array}$ & $\begin{array}{l}\text { Hardness } \\
(\mathrm{N})\end{array}$ & $\begin{array}{l}\text { Hardness after } 30 \mathrm{~s} \\
\text { soaking }(\mathrm{N})\end{array}$ & $\begin{array}{l}\mathrm{N}_{\mathrm{sr}} \\
\left(\mathrm{mm}^{-1}\right)\end{array}$ & $\begin{array}{l}\text { Density corrected hardness } \\
\left(\mathrm{N} . \mathrm{cm}^{3} / \mathrm{g}\right)\end{array}$ \\
\hline Kellogg's All-Bran & $171 \pm 4^{\mathrm{a}}$ & $1.1 \pm 0.1^{\mathrm{a}}$ & $28 \pm 5^{a}$ & $\underset{\mathrm{aA}}{277} \pm 9$ & $269 \pm 6^{\mathrm{aA}}$ & $0.4 \pm 0.1^{\mathrm{a}}$ & $1618 \pm 50^{\mathrm{a}}$ \\
\hline $\begin{array}{l}\text { Control wheat, standard } \\
\text { process }\end{array}$ & $399 \pm 22^{b}$ & $0.9 \pm 0.1^{\mathrm{ab}}$ & $12 \pm 1^{b}$ & $\underset{\mathrm{bcA}}{441} \pm 32$ & $322 \pm 38^{\mathrm{aB}}$ & $1.1 \pm 0.2^{b}$ & $1110 \pm 113^{b}$ \\
\hline $\begin{array}{l}\text { Control wheat, modified } \\
\text { process }\end{array}$ & $324 \pm 17^{b}$ & $0.9 \pm 0.1^{\mathrm{ab}}$ & $15 \pm 1^{b}$ & $\underset{\mathrm{bcA}}{438} \pm 18$ & $311 \pm 61 \mathrm{aB}$ & $\begin{array}{l}0.7 \pm 0.1 \\
\mathrm{ab}\end{array}$ & $1353 \pm 30^{a b}$ \\
\hline $\begin{array}{l}\text { Sprouted wheat, standard } \\
\text { process }\end{array}$ & $198 \pm 21^{\mathrm{a}}$ & $0.6 \pm 0.1^{c}$ & $20 \pm 1^{c}$ & $\begin{array}{l}439 \\
\mathrm{cA}\end{array}$ & $332 \pm 89$ aA & $0.3 \pm 0.1^{\mathrm{a}}$ & $2216 \pm 61^{c}$ \\
\hline $\begin{array}{l}\text { Sprouted wheat, modified } \\
\text { process }\end{array}$ & $335 \pm 39^{b}$ & $\underset{\mathrm{abc}}{0.8} \pm 0.1$ & $16 \pm 2^{b}$ & $\underset{\text { bcA }}{451} \pm 13$ & $338 \pm 71^{a B}$ & $\underset{\mathrm{ab}}{0.7 \pm 0.2}$ & $1368 \pm 176^{\mathrm{ab}}$ \\
\hline $\begin{array}{l}\text { Blend, } \\
\text { Standard process }\end{array}$ & $340 \pm 1^{b}$ & $0.7 \pm 0.1 b c$ & $15 \pm 1^{b}$ & $\underset{\text { bcA }}{499} \pm 3$ & $397 \pm 53^{a B}$ & $0.5 \pm 0.1^{\mathrm{a}}$ & $1468 \pm 6^{a b}$ \\
\hline Blend, modified process & $366 \pm 11^{b}$ & $0.9 \pm 0.1^{\mathrm{ab}}$ & $14 \pm 1^{b}$ & $\underset{\mathrm{bA}}{547} \pm 5$ & $403 \pm 48^{\mathrm{aB}}$ & $0.5 \pm 0.1^{\mathrm{a}}$ & $1498 \pm 30^{\mathrm{ab}}$ \\
\hline
\end{tabular}

\subsection{Texture of the breakfast flakes before and after soaking}

The breakfast flakes produced here were harder $(400-550 \mathrm{~N})$ than the commercial ones $(280 \mathrm{~N})$ but less hard than bran-rich breakfast flakes (550-900 N) made by De Brier et al. (2015). High concentrations of dietary fibre in bran-rich breakfast flakes allow less water to evaporate at the die, decrease the expansion and increase the hardness (Brennan et al., 2008). Moreover, dietary fibre can rupture gas cells, thereby reducing the overall expansion and again increasing hardness (Charunuch, Limsangouan, Prasert, \& Wongkrajang, 2014; Oliveira, Alencar, \& Steel, 2018). Finally, starch-fibre interactions reduce elasticity and weaken the cell structure, leading to harder structures (Oliveira et al., 2017, 2018).

One factor which definitely impacts the hardness of cellular materials is their (bulk) density. When we corrected the obtained hardness values for flake bulk density as done earlier by De Brier et al. (2015), the obtained intrinsic hardness readings for flakes derived from (blends containing) sprouted wheat $\left(1.5-2.2 \mathrm{kN} \mathrm{cm}^{3} / \mathrm{g}\right)$ were higher than those of flakes made from control wheat $\left(1.1-1.4 \mathrm{kN} \mathrm{cm}^{3} / \mathrm{g}\right)$. This may be because of the impact of the earlier action of amylase on starch on its crystallinity after cooling. Much as what happens during bread cooling after baking, amylose crystallised during cooling of the extruded and roasted breakfast flakes. The resulting network together with the thermoset gluten one contributes to the initial hardness of the flakes (Bosmans, Lagrain, Fierens, \& Delcour, 2013;Bosmans, Lagrain, Ooms, Fierens, \& Delcour, 2013). Amylase action impacts on amylose and causes it to crystallise more effectively during cooling. Such fast formation of a rigid network with prevention of structure collapse may lead to increased hardness (Bosmans, Lagrain, Fierens, \& Delcour, 2013; Goesaert, Leman, Bijttebier, \& Delcour, 2009; Lagrain, Leman, Goesaert, \& Delcour, 2008). Much as observed for the bulk density results (cfr. 3.2), the density corrected hardness readings for the flakes derived from sprouted wheat produced using the modified process $(1.4 \mathrm{kN})$ were not significantly different from those of flakes made from control wheat (1.1-1.4 kN). This confirms that the conditions used in the modified process $\left(50{ }^{\circ} \mathrm{C}, \mathrm{pH} 3.8\right)$ negatively impacted $\alpha$-amylase action.

Further, no clear differences were observed in $\mathrm{N}_{\mathrm{sr}}$, which is a measure for crispness. The higher $\mathrm{N}_{\mathrm{sr}}$, the more brittle the sample, which in sensory terms is perceived as more crispy and of better quality (De Brier et al., 2015). However, the here obtained values (0.3-
$1.1 \mathrm{~mm}^{-1}$ ) were rather low when compared to values $\left(0.6-2.0 \mathrm{~mm}^{-1}\right)$ for bran-rich breakfast flakes obtained by De Brier et al. (2015).

The soaking process in milk did not significantly affect the hardness of commercial flakes (Table 2). However, when the control breakfast flakes were soaked for $30 \mathrm{~s}$ their hardness already decreased by about $120 \mathrm{~N}$, which corresponded to a loss of $27 \%$ of their initial hardness. Similar trends (loss of 20-24\%) were observed both for flakes made from sprouted wheat or from the blend with the standard or modified production process. The present results are in line with those of De Brier et al. (2015) who, for flakes containing $40 \mathrm{~g} / 100 \mathrm{~g}$ bran or aleurone enriched bran, observed a loss of $12-23 \%$ of the initial hardness upon soaking for $30 \mathrm{~s}$. Finally, crispness (measured as $\mathrm{N}_{\mathrm{sr}}$ ) was lost after soaking all flake types in milk for $30 \mathrm{~s}$ (data not shown). De Brier et al. (2015) earlier observed that bran-rich flakes lose their crispness already during the first seconds of soaking.

\subsection{Soluble saccharide contents in the breakfast flakes}

Table 3 represents the saccharide contents of the breakfast flakes produced using either the standard or the modified process and an ingredient bill which included $7.5 \mathrm{~g} / 100 \mathrm{~g}$ sucrose and $2.5 \mathrm{~g} / 100 \mathrm{~g}$ glucose. The sucrose content of the commercial flakes amounted to about $15 \mathrm{~g} / 100 \mathrm{~g}$ of $\mathrm{dm}$, in line with the data on the label (data not shown). The use of sprouted wheat in the standard process increased the levels of maltose and maltotriose obviously as a result of $\alpha$-amylase action. Kruma et al. (2018) noted a saccharide (mainly sucrose and maltose) content of $1.5 \mathrm{~g} / 100 \mathrm{~g}$ of $\mathrm{dm}$ when using $40 \mathrm{~g} / 100 \mathrm{~g}$ sprouted cereals (triticale, oat and barley), but $2.2 \mathrm{~g} / 100 \mathrm{~g}$ of dm when using $50 \mathrm{~g} /$ $100 \mathrm{~g}$ of sprouted cereals (rye, oats and barley) in breakfast flakes produced by manual flaking and subsequent microwave-vacuum drying at temperatures not exceeding $45 \pm 5{ }^{\circ} \mathrm{C}$. They attributed the increase in saccharide content to enzymatic hydrolysis of starch. This raises the question whether this amylolytic activity has an impact on the carbohydrate availability and therefore also the glycaemic response of breakfast flakes derived from sprouted wheat. Unfortunately, there is no consensus in literature on the impact of sprouting cereal grains on in vitro starch digestibility. We kindly refer to the review paper by Lemmens, De Brier, Goos, Smolders, and Delcour (2019) for further information on this topic. Further, when using a whole meal blend containing only $25 \mathrm{~g} / 100 \mathrm{~g}$ of sprouted wheat and $75 \mathrm{~g} / 100 \mathrm{~g}$ of control wheat in the standard process the maltose and maltotriose contents in the resulting flakes were similar to those in the flakes derived from $100 \%$ sprouted wheat. This indicates that $\alpha$-amylase from sprouted wheat can 
Table 3

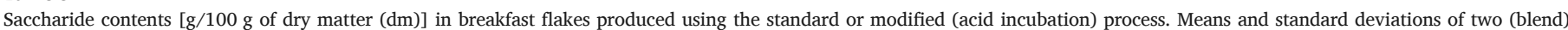

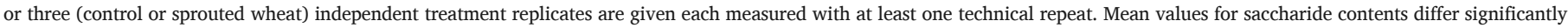
$(\mathrm{P}<0.05)$ when not sharing the same letter.

\begin{tabular}{|c|c|c|c|c|c|}
\hline Breakfast flake type & $\begin{array}{l}\text { Glucose }(\mathrm{g} / 100 \mathrm{~g} \text { of } \\
\mathrm{dm})\end{array}$ & $\begin{array}{l}\text { Fructose }(\mathrm{g} / 100 \mathrm{~g} \text { of } \\
\mathrm{dm})\end{array}$ & $\begin{array}{l}\text { Sucrose }(\mathrm{g} / 100 \mathrm{~g} \text { of } \\
\mathrm{dm})\end{array}$ & $\begin{array}{l}\text { Maltose }(\mathrm{g} / 100 \mathrm{~g} \text { of } \\
\mathrm{dm})\end{array}$ & $\begin{array}{l}\text { Maltotriose }(\mathrm{g} / 100 \mathrm{~g} \text { of } \\
\mathrm{dm})\end{array}$ \\
\hline Control wheat, standard process & $1.91 \pm 0.03^{\mathrm{a}}$ & $0.20 \pm 0.12^{a b}$ & $7.55 \pm 0.32 \mathrm{ab}$ & $1.87 \pm 0.08^{\mathrm{ab}}$ & $0.01 \pm 0.01^{\mathrm{a}}$ \\
\hline Control wheat, modified process & $2.08 \pm 0.21^{\mathrm{a}}$ & $0.28 \pm 0.07$ abc & $7.77 \pm 0.04$ ab & $1.42 \pm 0.07^{b}$ & $0.02 \pm 0.01^{\mathrm{a}}$ \\
\hline $\begin{array}{l}\text { Sprouted wheat, standard } \\
\text { process }\end{array}$ & $1.57 \pm 0.12^{\mathrm{a}}$ & $0.42 \pm 0.05$ acd & $7.20 \pm 0.23$ & $2.92 \pm 0.14^{c}$ & $0.54 \pm 0.04^{b}$ \\
\hline $\begin{array}{l}\text { Sprouted wheat, modified } \\
\text { process }\end{array}$ & $1.92 \pm 0.41^{\mathrm{a}}$ & $0.66 \pm 0.07^{\mathrm{d}}$ & $6.95 \pm 0.04^{b}$ & $1.55 \pm 0.07^{b}$ & $0.21 \pm 0.01^{\mathrm{c}}$ \\
\hline $\begin{array}{l}\text { Blend, } \\
\text { Standard process }\end{array}$ & $1.70 \pm 0.03^{\mathrm{a}}$ & $0.09 \pm 0.04^{b}$ & $8.05 \pm 0.02^{\mathrm{a}}$ & $2.74 \pm 0.03^{c}$ & $0.19 \pm 0.01^{\mathrm{c}}$ \\
\hline Blend, modified process & $2.02 \pm 0.02^{\mathrm{a}}$ & $0.56 \pm 0.02^{\mathrm{cd}}$ & $7.17 \pm 0.23 a b$ & $2.50 \pm 0.03 \mathrm{ac}$ & $0.21 \pm 0.01^{\mathrm{c}}$ \\
\hline
\end{tabular}

act on starch present in control wheat as well. Finally, when using sprouted wheat in the modified process, the maltose and maltotriose contents in the resulting flakes were lower than when using sprouted wheat in the standard process. This observation again confirms that the conditions used in the modified process $\left(50{ }^{\circ} \mathrm{C}, \mathrm{pH} 3.8\right)$ negatively impacted $\alpha$-amylase action.

The relative sweetness of control breakfast flakes prepared using the standard process amounted to about 10.0, while it was approximately 10.5 for flakes manufactured from sprouted wheat. As the ingredient bill included relatively high levels of added sugars (7.5 g/100 g sucrose and $2.5 \mathrm{~g} / 100 \mathrm{~g}$ glucose) the difference in relative sweetness between the two flake types was not significant $(\mathrm{P}>0.05)$. However, sprouted wheat containing high levels of maltose and maltotriose can result in higher sweetness of breakfast flakes and thus can be used to reduce the level of sugar addition.

\subsection{Phytate contents during the production of breakfast flakes}

During the standard production of breakfast flakes, the highest phytate breakdown was observed either during extrusion or during roasting (Fig. 1). However, it was limited to only $15-20 \%$ and did not depend on the use of control or (blend containing) sprouted wheat. Still, the lowest phytate level $(0.61 \mathrm{~g} / 100 \mathrm{~g}$ of $\mathrm{dm})$ was observed in breakfast flakes derived from sprouted wheat.
Reductions in phytate content of $10-45 \%$ have been noted when extruding whole meal from (sprouted) wheat and barley (Singkhornart et al., 2013), a mixture of wheat bran, starch and gluten (Andersson, Hedlund, Jonsson, \& Svensson, 1981) or a corn starch-based flour recipe containing common bean flour (Anton, Fulcher, \& Arntfield, 2009). Heating and/or shear during extrusion or roasting can lead to breakdown/hydrolysis of phytate (Embaby, 2011; Udensi, Ekwu, \& Isinguzo, 2007).

The endogenous phytase activity in control wheat is relatively high (Lemmens, De Brier et al., 2019). Here, it decreased the phytate content from $0.84 \mathrm{~g} / 100 \mathrm{~g}$ of $\mathrm{dm}$ to $0.65 \mathrm{~g} / 100 \mathrm{~g}$ of $\mathrm{dm}$ in control wheat during the resting step in the modified production process ("after resting", cfr. Fig. 1). After extrusion, the phytate content amounted to only $0.46 \mathrm{~g} / 100 \mathrm{~g}$ of $\mathrm{dm}$ using this process. Endogenous phytase can remain active at temperatures exceeding $80{ }^{\circ} \mathrm{C}$ (Peers, 1953).

When applying the modified production process using sprouted wheat, we again noted a decrease in phytate content from $0.76 \mathrm{~g} / 100 \mathrm{~g}$ of $\mathrm{dm}$ to $0.54 \mathrm{~g} / 100 \mathrm{~g}$ of $\mathrm{dm}$ after resting at $50{ }^{\circ} \mathrm{C}$. However, the final phytate content in these breakfast flakes $(0.43 \mathrm{~g} / 100 \mathrm{~g}$ of $\mathrm{dm})$ was similar to that obtained for control wheat. This indicates that elevated endogenous phytase activity as a result of sprouting did not lead to more extensive phytate hydrolysis during this process. When using whole meal blends containing only $25 \mathrm{~g} / 100 \mathrm{~g}$ of sprouted wheat and $75 \mathrm{~g} /$ $100 \mathrm{~g}$ of control wheat in the modified production process the phytate content in the resulting flakes was about $0.50 \mathrm{~g} / 100 \mathrm{~g}$ of dm.

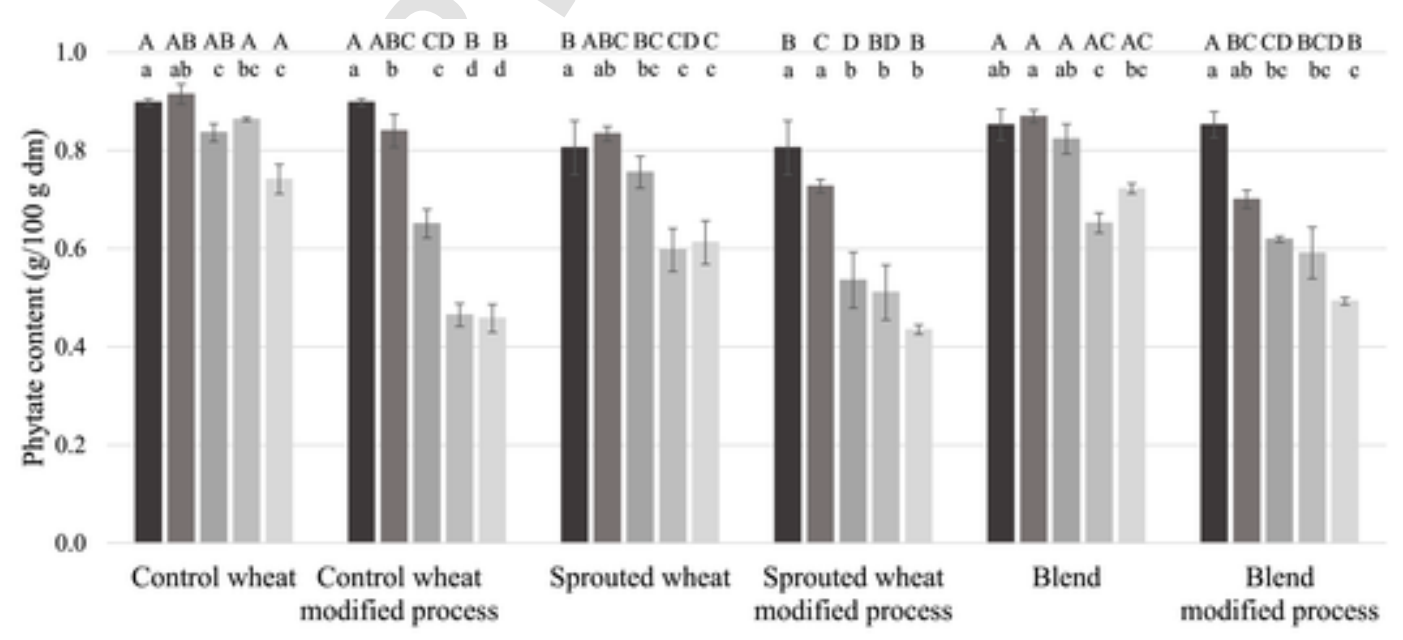

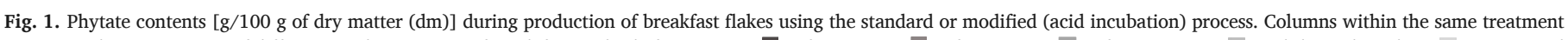

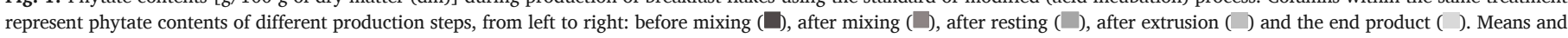

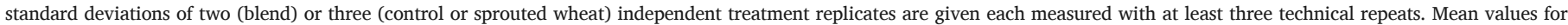

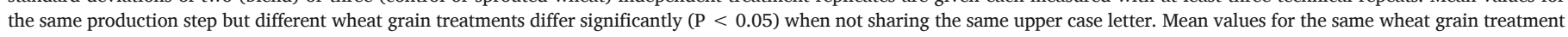
but different production steps differ significantly $(\mathrm{P}<0.05)$ when not sharing the same lower case letter. 


\subsection{Iron and zinc bio-accessibilities in the breakfast flakes}

During breakfast flake making with the standard process, $15-20 \%$ of phytate was broken down (cfr. 3.5). Here, we investigated in vitro whether this decrease enhanced Fe and Zn bio-accessibility. The Fe and $\mathrm{Zn}$ bio-accessibility values were both $8 \%$ in flakes made with control wheat (Table 4). The use of sprouted wheat in the same production process sharply increased Fe bio-accessibility to $28 \%$ and improved $\mathrm{Zn}$ bio-accessibility to $14 \%$. It is thus of use to substitute control wheat (partly) by sprouted wheat if one aims to increase mineral bio-accessibility in whole meal products.

The isothermal step for $60 \mathrm{~min}$ at $50{ }^{\circ} \mathrm{C}$ and $\mathrm{pH} 3.8$ as part of the production of breakfast flakes decreased the phytate content by about $50 \%$ in both whole meal from control and sprouted wheat and the blend thereof. As a result, the Fe bio-accessibility increased to about $38 \%$ and that of $\mathrm{Zn}$ to between 17 and $32 \%$ (Table 4). The modified process was most effective at reducing phytate content and increasing Fe and Zn bio-accessibility for control wheat, sprouted wheat and the blend made thereof.

The linear relationship between phytate content and $\mathrm{Fe}\left(\mathrm{R}^{2}=0.95\right)$ and $\mathrm{Zn}\left(\mathrm{R}^{2}=0.62\right)$ bio-accessibility in breakfast flakes (Fig. 2) suggested that lower phytate contents render $\mathrm{Fe}$ and $\mathrm{Zn}$ more accessible in the human gastro-intestinal tract. The highest Fe bio-accessibility value of $38 \%$ was reached at a phytate content of $0.49 \mathrm{~g} / 100 \mathrm{~g}$ of $\mathrm{dm}$. A further decrease in phytate content to $0.43 \mathrm{~g} / 100 \mathrm{~g}$ of $\mathrm{dm}$ was not reflected in a different level of Fe bio-accessibility (Fig. 2). It is likely that a decrease in phytate content of only $0.06 \mathrm{~g} / 100 \mathrm{~g}$ of $\mathrm{dm}$ was not

Table 4

Iron and zinc bio-accessibilities (\%) in the breakfast flakes produced using the standard or modified (acid incubation) process. Means and standard deviations of two (blend) or three (control or sprouted wheat) independent treatment replicates are given each measured with at least two technical repeats. Mean values within one column differ significantly $(\mathrm{P}<0.05)$ when not sharing the same letter.

\begin{tabular}{lll}
\hline Breakfast flake type & $\begin{array}{l}\text { Iron bio-accessibility } \\
(\%)\end{array}$ & $\begin{array}{l}\text { Zinc bio-accessibility } \\
(\%)\end{array}$ \\
\hline $\begin{array}{l}\text { Control wheat, standard } \\
\text { process }\end{array}$ & $8.1 \pm 0.8^{\mathrm{a}}$ & $8.1 \pm 4.5^{\mathrm{a}}$ \\
$\begin{array}{l}\text { Control wheat, modified } \\
\text { process }\end{array}$ & $38.1 \pm 3.5^{\mathrm{b}}$ & $26.9 \pm 1.0^{\mathrm{bc}}$ \\
$\begin{array}{l}\text { Sprouted wheat, standard } \\
\text { process }\end{array}$ & $27.7 \pm 2.3^{\mathrm{c}}$ & $13.9 \pm 1.6^{\mathrm{a}}$ \\
$\begin{array}{l}\text { Sprouted wheat, modified } \\
\text { process }\end{array}$ & $37.7 \pm 5.4^{\mathrm{b}}$ & $17.1 \pm 0.5^{\mathrm{ac}}$ \\
$\begin{array}{l}\text { Blend, standard process } \\
\text { Blend, modified process }\end{array}$ & $14.8 \pm 2.6^{\mathrm{a}}$ & $10.0 \pm 1.6^{\mathrm{a}}$ \\
\hline
\end{tabular}

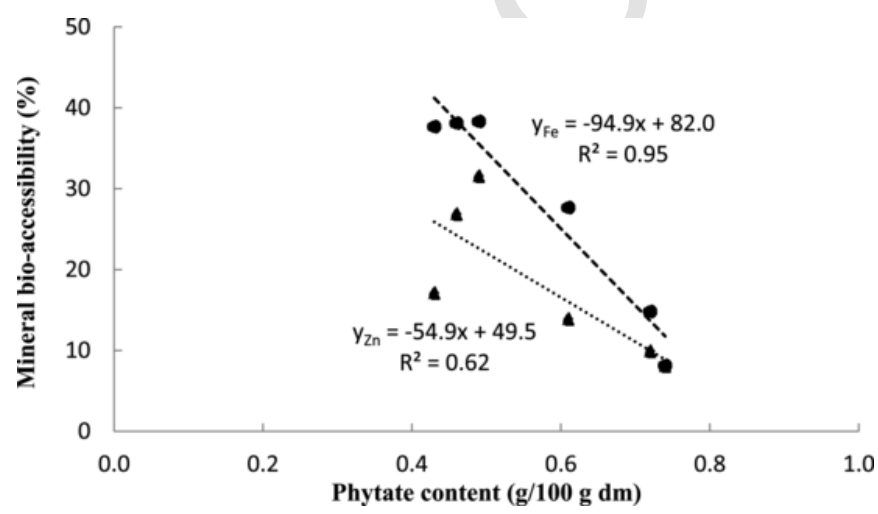

Fig. 2. Linear correlation between iron $(\bullet)$ and zinc $(\boldsymbol{\bullet})$ bio-accessibilities (\%) and phytate content $[\mathrm{g} / 100 \mathrm{~g}$ of dry matter $(\mathrm{dm})]$ in breakfast flakes. The $\mathrm{R}^{2}$ value and the equation of both linear regressions are given. sufficient to increase the Fe bio-accessibility further. Indeed, Lemmens et al. (2018) found a Fe bio-accessibility value of about $37 \%$ in whole meal derived from hydrothermally processed wheat with a phytate content of $0.11 \mathrm{~g} / 100 \mathrm{~g}$ of $\mathrm{dm}$. In addition, the linear relationship between phytate content and $\mathrm{Zn}$ bio-accessibility had a $\mathrm{R}^{2}$ value of only 0.62 (Fig. 2). The latter can be explained by the fact that no significant differences in Zn bio-accessibility were found between control breakfast flakes prepared using the standard process and breakfast flakes derived from sprouted wheat (Table 4). Given the above, not only phytic acid limits the mineral bio-accessibility, but other factors were in play as well. These can include the presence of plant cell walls which causes minerals to be physically entrapped (Amrein, Gränicherb, Arrigonia, \& Amadoa, 2003; Lemmens, De Brier et al., 2019), the formation of (in)soluble complexes with dietary fibres decreasing the absorption of minerals (Baye, Guyot, \& Mouquet-Rivier, 2015; Persson, Nyman, Liljeberg, Önning, \& Frolich, 1991) and the restricted solubility of minerals such as Zn (Silva et al., 2020) and Fe (Hungerford \& Linder, 1983) at the $\mathrm{pH}$ of the gastrointestinal environment.

The question how these in vitro mineral bio-accessibility values of breakfast flakes relate to their in vivo mineral bio-availability values is a valid one (cfr. 2.5). It has been stated that in order to accomplish a $c a$. twofold increase in Fe absorption from food, the molar ratio of phytate to Fe needs to be maximally 1 (Allen, de Benoist, Dary, \& Hurrel, 2006; Hurrell, 2004). Here, the phytate to Fe molar ratio in control wheat flakes produced using the standard process amounted to about 20 (data not shown). Earlier, Magallanes-López et al. (2017) reported phytate to Fe molar ratios of 12.1-29.6 in 46 durum wheat varieties. In the present case, the phytate to Fe molar ratio decreased to about 12 with the modified production process for breakfast flakes derived from whole meal of control and sprouted wheat and the blend thereof. Further, the phytate to $\mathrm{Zn}$ molar ratio of control wheat flakes produced using the standard process amounted to about 38, decreasing to about 22 in flakes produced using the modified process (data not shown). Comparable phytate to $\mathrm{Zn}$ molar ratios of 17-37 in wheat were found by other authors (Hemalatha, Platel, \& Srinivasan, 2007; Magallanes-López et al., 2017; Wang, Liu, Pan, Yuan, \& Yin, 2015). At high molar ratios (i.e. above 15), $\mathrm{Zn}$ absorption from food is predicted to be less than $15 \%$ (Allen et al., 2006). Based on these results, an even further breakdown of phytate is needed to increase the mineral bio-availability in breakfast flakes. However, an in vivo study is needed to confirm this hypothesis.

Larsson, Rossander-Hulthén, Sandström, and Sandberg (1996) showed that $\mathrm{Fe}$ and $\mathrm{Zn}$ absorption in humans increased from 4 to $6 \%$ and $12-18 \%$, respectively, when consuming a breakfast meal containing malted oat porridge (in which $75 \%$ of phytate was hydrolysed) rather than a meal containing non-malted oat porridge. Further, Fredlund et al. (2003) noted an increase in Zn absorption from 15 to $23 \%$ with a group of ten healthy subjects when serving them breakfast cereals based on malted barley that contained $30 \%$ less phytate rather than breakfast cereals of non-processed barley.

\section{Conclusions}

This study, for the first time, not only showed the feasibility but also the advantages of manufacturing breakfast flakes by extrusion using whole meal from sprouted wheat. The resulting flakes were indeed of good quality with acceptable colour, bulk density and hardness before and after soaking for $30 \mathrm{~s}$ in semi-skimmed milk. Further, using sprouted wheat in the standard production process increased maltose and maltotriose contents. This offers opportunities to reduce the level of sugar addition in breakfast flakes. As a result, less empty calories are present which increases the nutritional value of the resulting flakes. Indeed, when substituting sucrose with whole meal derived from sprouted wheat in the recipe, the resultant flakes on a weight basis 
have higher dietary fibre, vitamin and mineral contents. These intrinsic sugars deliver sweet notes to the product and serve as flavour precursors in Maillard reactions leading to caramel and toast aromas. Moreover, resting the ingredient mixture at $50{ }^{\circ} \mathrm{C}$ and $\mathrm{pH} 3.8$ for $1 \mathrm{~h}$ prior to flake production led to a $45-60 \%$ phytate breakdown in the flakes. As a result, a fourfold to fivefold increase in Fe bio-accessibility and a twofold to fourfold increase in $\mathrm{Zn}$ bio-accessibility was found compared to the standard process. That the final phytate contents in breakfast flakes derived from whole meal of control and sprouted wheat were similar indicates that elevated endogenous phytase activity as a result of sprouting did not lead to more extensive phytate hydrolysis during the process.

To conclude, by fully exploiting the nutritional profile of wheat grains, palatable whole grain breakfast flakes with a clean label (no added sugars or minerals) can be obtained which meet consumer demands and needs.

\section{Declaration of competing interest}

The authors declare that they do not have any conflict of interest. No industrial partner was involved in developing the research protocols or in performing the analyses.

\section{Acknowledgements}

This research was conducted in the framework of the W.K. Kellogg Chair in Cereal Science and Nutrition at the KU Leuven (chair holders J.A. Delcour and K. Verbeke) and is part of the Methusalem program "Food for the Future" (2007-2021). Fruitful discussions with professor Peter Goos (KU Leuven) on the statistical analyses are highly appreciated.

\section{References}

Agbisit, R., Alavi, S., Cheng, E., Herald, T., \& Trater, A. (2007). Relationships between microstructure and mechanical properties of cellular cornstarch extrudates. Journal of Texture Studies, 38, 199-219.

Ajandouz, E.H., Tchiakpe, L.S., Dalle Ore, F., Benajiba, A., \& Puigserver, A. (2001). Effects of $\mathrm{pH}$ on caramelization and Maillard reaction kinetics in fructose-lysine model systems. Journal of Food Science, 66, 926-931.

Allen, L., de Benoist, B., Dary, O., \& Hurrel, R. (2006). Guidelines on food fortification with micronutrients World Health Organization and. Food and Agriculture Organization of the United Nations.

Amrein, T.M., Gränicherb, P., Arrigonia, E., \& Amadoa, R. (2003). In vitro digestibility and colonic fermentability of aleurone isolated from wheat bran. LWT- Food Science and Technology, 36, 451-460.

Andersson, Y., Hedlund, B., Jonsson, L., \& Svensson, S. (1981). Extrusion cooking of a high-fiber cereal product with crispbread character. Cereal Chemistry, 58, 370-374.

Anton, A.A., Fulcher, R.G., \& Arntfield, S.D. (2009). Physical and nutritional impact of fortification of corn starch-based extruded snacks with common bean (Phaseolus vulgaris L.) flour: Effects of bean addition and extrusion cooking. Food Chemistry, 113, 989-996.

Baye, K., Guyot, J., \& Mouquet-Rivier, C. (2015). The unresolved role of dietary fibers on mineral absorption. Critical Reviews in Food Science and Nutrition, 57, 949-957.

Bewley, J.D., Bradford, K.J., Hilhorst, H.W.M., \& Nonogaki, H. (Eds.). (2013). Seeds: Physiology of development, germination and dormancy. New York, USA: Springer.

van Boekel, M.A.J.S. (2006). Formation of flavour compounds in the Maillard reaction. Biotechnology Advances, 24, 230-233.

Bosmans, G.M., Lagrain, B., Fierens, E., \& Delcour, J.A. (2013). Impact of amylases on biopolymer dynamics during storage of straight-dough wheat bread. Journal of Agricultural and Food Chemistry, 61, 6525-6532.

Bosmans, G.M., Lagrain, B., Ooms, N., Fierens, E., \& Delcour, J.A. (2013). Biopolymer interactions, water dynamics, and bread crumb firming. Journal of Agricultural and Food Chemistry, 61, 4646-4654.

Brennan, M.A., Derbyshire, E., Tiwari, B.K., \& Brennan, C.S. (2013). Ready-to-eat snack products: The role of extrusion technology in developing consumer acceptable and nutritious snacks. International Journal of Food Science and Technology, 48, 893-902.

Brennan, M.A., Merts, I., Monro, J., Woolnough, J., \& Brennan, C.S. (2008). Impact of guar gum and wheat bran on the physical and nutritional quality of extruded breakfast cereals. Starch Staerke, 60, 248-256.

Cerny, C., \& Brifford, M. (2007). Effect of $\mathrm{pH}$ on the Maillard reaction of $\left[{ }^{13} \mathrm{C} 5\right]$ xylose, cysteine, and thiamin. Journal of Agricultural and Food Chemistry, 55, 1552-1556.

Charunuch, C., Limsangouan, N., Prasert, W., \& Wongkrajang, K. (2014). Optimization of extrusion conditions for ready-to-eat breakfast cereal enhanced with defatted rice bran. International Food Research Journal, 21, 713-722.
Coghe, S., Gheeraert, B., Michiels, A., \& Delvaux, F.R. (2006). Development of Maillard reaction related characteristics during malt roasting. Journal of the Institute of Brewing, 112, 148-156.

De Brier, N., Gomand, S.V., Donner, E., Paterson, D., Smolders, E., \& Delcour, J.A., et al. (2016). Element distribution and iron speciation in mature wheat grains (Triticum aestivum L.) using synchrotron X-ray fluorescence microscopy mapping and X-ray absorption near-edge structure (XANES) imaging. Plant, Cell and Environment, 39, 1835-1847.

De Brier, N., Gomand, S.V., Joye, I.J., Pareyt, B., Courtin, C.M., \& Delcour, J.A. (2015). The impact of pearling as a treatment prior to wheat roller milling on the texture and structure of bran-rich breakfast flakes. LWT- Food Science and Technology, 62 , 668-674.

Ding, Q., Ainsworth, P., Plunkett, A., Tucker, G., \& Marson, H. (2006). The effect of extrusion conditions on the functional and physical properties of wheat-based expanded snacks. Journal of Food Engineering, 73, 142-148.

Duke, S.H. (2009). A comparison of barley malt amylolytic enzyme activities as indicators of malt sugar concentrations. Journal of the American Society of Brewing Chemists, 67, 99-111.

Embaby, H. (2011). Effect of heat treatments on certain antinutrients and in vitro protein digestibility of peanut and sesame seeds. Food Science and Technology Research, 17, 31-38.

Fredlund, K., Bergman, E., Rossander-Hulthén, L., Isaksson, M., Almgren, A., \& Sandberg, A. (2003). Hydrothermal treatment and malting of barley improved zinc absorption but not calcium absorption in humans. European Journal of Clinical Nutrition, 57, 1507-1513.

Goesaert, H., Leman, P., Bijttebier, A., \& Delcour, J.A. (2009). Antifirming effects of starch degrading enzymes in bread crumb. Journal of Agricultural and Food Chemistry, 57, 2346-2355.

Greiner, R., Jany, K., \& Alminger, M.L. (2000). Identification and properties of myo-inositol hexakisphosphate phosphohydrolases (phytases) from barley (Hordeum vulgare). Journal of Cereal Science, 31, 127-139.

Heiniö, R., Katina, K., Wilhelmson, A., Myllymäki, O., Rajamäki, T., \& Latva-Kala, K., et al. (2003). Relationship between sensory perception and flavour-active volatile compounds of germinated, sourdough fermented and native rye following the extrusion process. Lebensmittel-Wissenschaft und Technologie. 2003.

Hemalatha, S., Platel, K., \& Srinivasan, K. (2007). Zinc and iron contents and their bioaccessibility in cereals and pulses consumed in India. Food Chemistry, 102, 1328-1336.

Hungerford, D.M., \& Linder, M.C. (1983). Interactions of $\mathrm{pH}$ and ascrobate in intestinal iron absorption. Journal of Nutrition, 113, 2615-2622.

Hurrell, R.F. (2004). Phytic acid degradation as a means of improving iron absorption. International Journal for Vitamin and Nutrition Research, 74, 445-452.

Ibraheem, N.A., Hasan, M.M., Khan, R.Z., \& Mishra, P.K. (2012). Understanding color models: A review. ARPN Journal of Science and Technology, 2, 265-275.

Joye, I.J., Lamberts, L., Brijs, K., \& Delcour, J.A. (2011). In situ production of $\gamma$-aminobutyric acid in breakfast cereals. Food Chemistry, 129, 395-401.

Karseno, E., Yanto, T., Setyowati, R., \& Haryanti, P. (2017). Effect of pH and temperature on browning intensity of coconut sugar and its antioxidant activity. Food Research, 2, 32-38.

Kince, T., Galoburda, R., Klava, D., Tomsone, L., Senhofa, S., \& Straumite, E., et al. (2017). Breakfast cereals with germinated cereal flakes: Changes in selected physical, microbiological, and sensory characteristics during storage. European Food Research and Technology, 243, 1-10.

Kruma, Z., Galoburda, R., Tomsone, L., Gramatina, I., Senhofa, S., \& Straumite, E., et al. (2018). Changes in the nutritional value of breakfast cereals containing germinated spring grain flakes during storage. Agronomy Research, 16, 1405-1416.

Lagrain, B., Leman, P., Goesaert, H., \& Delcour, J.A. (2008). Impact of thermostable amylases during bread making on wheat bread crumb structure and texture. Food Research International, 41, 819-827.

Larsson, M., Rossander-Hulthén, L., Sandström, B., \& Sandberg, A. (1996). Improved zinc and iron absorption from breakfast meals containing malted oats with reduced phytate content. British Journal of Nutrition, 76, 677-688.

Lasekan, O.O., Lasekan, W.O.I., \& M.A. (1997). Flavour volatiles of malt beverage from roasted Sorghum. Food Chemistry, 58, 341-344.

Lavic (2011). Relative sweetness values for various sweeteners. https://owlsoft.com/ pdf_docs/WhitePaper/Rel_Sweet.pdf.

Le Corre, A. (2006). Ready-to-eat breakfast cereal manufacturing: Use of twin-screw extrusion technology to produce multiple products. Cereal Foods World, 51, 302-305.

Lemmens, E., De Brier, N., Goos, P., Smolders, E., \& Delcour, J.A. (2019). Steeping and germination of wheat (Triticum aestivum L.). I. Unlocking the impact of phytate and cell wall hydrolysis on the bio-accessibility of iron and zinc elements. Journal of Cereal Science, 90, 1-9.

Lemmens, E., De Brier, N., Spiers, K.M., Ryan, C.G., Garrevoet, J., \& Falkenberg, G., et al. (2018). The impact of steeping, germination and hydrothermal processing of wheat (Triticum aestivum L.) grains on phytate hydrolysis and the distribution, speciation and bio-accessibility of iron and zinc elements. Food Chemistry, 264, 367-376.

Lemmens, E., Moroni, A.V., Pagand, J., Heirbaut, P., Ritala, A., \& Karlen, Y., et al. (2019). Impact of cereal seed sprouting on its nutritional and technological properties: A critical review. Comprehensive Reviews in Food Science and Food Safety, 18, 305-328.

Magallanes-López, A.M., Hernandez-Espinosa, N., Velu, G., Posadas-Romano, G., Ordoñez-Villegas, V.M.G., \& Crossa, J., et al. (2017). Variability in iron, zinc and phytic acid content in a worldwide collectionof commercial durum wheat cultivars and the effect of reduced irrigationon these traits. Food Chemistry, 237, 499-505.

Minekus, M., Alminger, M., Alvito, P., Ballance, S., Bohn, T., \& Bourlieu, C., et al. (2014). A standardised static in vitro digestion method suitable for food - an international consensus. Food \& Function, 5, 1113-1124. 
E. Lemmens et al.

LWT - Food Science and Technology $x x x(x x x x) x x x-x x x x$

Morris, E.R., \& Ellis, R. (1989). Usefulness of the dietary phytic acid/zinc molar ratio as an index of zinc bioavailability to rats and humans. Biological Trace Element Research, 19, 107-117.

Navale, S.A., Swami, S.B., \& Thakor, N.J. (2015). Extrustion cooking technology for foods: A review. Journal of Ready to Eat Food, 2, 66-80.

Oliveira, L.C., Alencar, N.M.M., \& Steel, C.J. (2018). Improvement of censorial and technological characteristics of extruded breakfast cereals enriched with whole grain wheat flour and jabuticaba (Myrciaria cauliflora) peel. LWT- Food Science and Technology, 90, 207-214.

Oliveira, L.C., Schmiele, M., \& Steel, C.J. (2017). Development of whole grain wheat flour extruded cereal and process impacts on color, expansion, and dry and bowl-life texture. LWT- Food Science and Technology, 75, 261-270.

Peers, F.G. (1953). The phytase of wheat. Biochemistry Journal, 53, 102-110.

Person, H., Nyman, M., Liljeberg, H., Önning, G., \& Frolich, W. (1991). Binding of mineral elements by dietary fibre components in cereals - in vito (III). Food Chemistry, 40, 169-183.

Sacchetti, G., Pittia, P., Biserni, M., Pinnavaia, G.G., \& Rosa, M.D. (2003). Kinetic modelling of textural changes in ready-to-eat breakfast cereals during soaking in semi-skimmed milk. International Journal of Food Science and Technology, 38, 135-143.

Sacchetti, G., Pittia, P., \& Pinnavaia, G.G. (2005). The effect of extrusion temperature and drying-tempering on both the kinetics of hydration and the textural changes in extruded ready-to-eat breakfast cereals during soaking in semi-skimmed milk. International Journal of Food Science and Technology, 40, 655-663.

Silva, M.S., Prabhu, P.A.J., Ornsrud, R., Sele, V., Kröckel, S., \& Sloth, J.J., et al. (2020). In vito digestion method to evaluate solubility of dietary zinc, selenium and manganese in salmonid diets. Journal of Trace Elements in Medicine \& Biology, 57, 152-159.
Singh, S., Gamlath, S., \& Wakeling, L. (2007). Nutritional aspects of food extrusion: A review. International Journal of Food Science and Technology, 42, 916-929.

Singh, K., \& Kayastha, A.M. (2014). $\alpha$-Amylase from wheat (Triticum aestivum) seeds: Its purification, biochemical attributes and active site studies. Food Chemistry, 162, 1-9.

Singkhornart, S., Gu, B., \& Ryu, G.H. (2013). Physicochemical properties of extruded germinated wheat and barley as modified by $\mathrm{CO}_{2}$ injection and difference extrusion conditions. International Journal of Food Science and Technology, 48, 290-299.

Than, B., Xie, B., Shi, J., Wu, J., Cai, Y., \& Xu, T., et al. (2010). Physicochemical changes of oat seeds during germination. Food Chemistry, 119, 1195-1200.

Udensi, E.A., Ekwu, F.C., \& Isinguzo, J.N. (2007). Antinutrient factors of vegetable cowpea (Sesquipedalis) seeds during thermal processing. Pakistan Journal of Nutrition, 6, 194-197.

Wang, Z., Lu, Q., Pan, F., Yuan, L., \& Yin, X. (2015). Effects of increasing rates of zinc fertilization on physic acid and phytic acid/zinc molar ratio in zinc bio-fortified wheat. Field Crops Research, 184, 58-64.

Wojtowicz, A., Mitrus, M., Oniszczuk, T., Moscicki, L., Krecisz, M., \& Oniszczuk, A. (2015). Selected physical properties, texture and sensory characteristics of extruded breakfast cereals based on wholegrain wheat flour. Agriculture and Agricultural Science Procedia, 7, 301-308.

Woods, J., \& Walker, K. (2007). Choosing breakfast: How well does packet information on Australian breakfast cereals, bars and drinks reflect recommendations. Nutrition and Dietetics, 64, 226-233.

9 